Огляди літератури, оригінальні дослідження, погляд на проблему

удК 616.33/.342-002.44-031.7:616.36]-02-056:159.942.972

DOI 10.11603/1811-2471.2018.v0.i1.8623

\title{
ГЕПАТОГЕННА ВИРАЗКА ТА ВИРАЗКОВА ХВОРОБА ДВАНАДЦЯТИПАЛОЇ КИШКИ: ОСОБЛИВОСТІ ПСИХОЕМОЦИЙНОГО СТАТУСУ ХВОРИХ
}

\section{๑О. М. Москаль, Е. Й. Архій}

ДВНЗ «Ужгородський національний університет»

РЕзЮМЕ. Гепатогенна виразка та виразкова хвороба дванадцятипалої кишки: особливості психоемоційного статусу хворих.

Мета - вивчення психологічного статусу особистості хворих на виразкову хворобу дванадцятипалої кишки і симптоматичну гепатогенну виразку та виявлення його відмінностей при даних захворюваннях.

Матеріал і методи. Обстежено 36 хворих, поділених на дві групи: 22 хворих із хронічними захворюваннями печінки та поєднаною патологією шлунково-кишкового тракту та 14 хворих на пептичну виразку дванадцятипалої кишки. Усім хворим проводили загальноклічні дослідження, для оцінки психологічного статусу були проведені набори анкетних тестів: тест Люшера (тест вибору кольору), тест САН (тест диференційної самооцінки функціонального стану), опитувальник Спілбергера (шкала реактивної та особистісної тривожності) та опитувальник Айзенка (для визначення рівня нейротизму і показників екстра- та інтроверсії). Результати тестування оцінювали в балах.

Результати. За методикою Люшера, як при симптоматичній гепатогенній виразці, так і при виразковій хворобі дванадцятипалої кишки, значно підвищена тривога супроводжується нестійкістю емоційної сфери. Загальний стан хворих за даними САН погіршується в обох групах пацієнтів і значно покращується під впливом лікування, хоч далеко не всі показники повністю нормалізуються. Аналізуючи отримані нами дані за методикою Спілбергера ми виявили підвищені рівні реактивної та особистісної тривожності в обох групах хворих та достовірне їх зниження після проведеного лікування. Тест Айзенка в обох групах досліджуваних нами хворих підтвердив односпрямованість психоемоційних порушень у хворих та їх покращення під впливом лікування. Однак, за його результатами, психоемоційний профіль жінок, хворих на виразкову хворобу дванадцятипалої кишки, погіршується значніше, ніж у чоловіків, на відміну від хворих на гепатогенну виразку жінок і чоловіків.

Висновки. У обох групах у обстежених хворих є виражені розлади психоемоційної сфери у вигляді тривожних та депресивних тенденцій, нестійкості емоційної сфери та невротизації особистості, що слід враховувати при проведенні терапії.

КлючОВІ СлОВА: гепатогенна виразка; виразкова хвороба дванадцятипалої кишки; психологічний статус.

Вступ. Не викликає сумніву, що виразкова хвороба шлунка i, особливо, виразкова хвороба дванадцятипалої кишки (ДПК) належить до психосоматичних захворювань [1]. Психосоматичні співвідношення при виразковій хворобі ДПК залишаються однією із найактуальніших проблем сучасної гастроентерології [2]. У кінці XX ст. були створені новітні схеми терапії цього захворювання, основою яких була ерадикація Helicobacter pylori (Hр), якому була відведена роль провідного фактора, що призводить до утворення виразок. Однак, не зважаючи на широке впровадження анти - Нр-терапії, як у нас, так і за кордоном число хворих з даною патологією не тільки не зменшилось, а й продовжує зростати [3]. До того ж, на сьогодні показано, що Нр виявляється не у всіх пацієнтів з виразковою хворобою ДПК, як вважали спочатку [4]. Багато вчених все більшого значення надають ролі психосоматичних факторів в ульцерогенезі [5]. Тому при розробці терапії слід враховувати не тільки соматичний компонент захворювання, а й психоемоційний статус хворого. Нервово-психічні порушення, які виникають при захворюваннях печінки, в тому числі при цирозах, давно привертають увагу клініцистів. Але до сьогодні ця проблема до кінця не вивчена. При роз- витку цирозу печінки та портальної гіпертензії спостерігається поступове поглиблення нервово-психічних порушень. Спочатку з'являються астенічні стани, в подальшому формується психоорганічний синдром, на фоні якого можуть періодично виникати психотичні стани [6].

Мета - вивчити психологічний статус особистості хворих на виразкову хворобу ДПК та симптоматичну гепатогенну виразку і виявити різницю у психологічному статусі хворих при даних захворюваннях.

Матеріал і методи дослідження. Ми обстежили 36 хворих, яких поділили на дві групи:

I група - пацієнти із хронічними захворюваннями печінки та патологією шлунково-кишкового тракту (ШКТ) - 22 хворих (61\%);

II група - пацієнти з пептичною виразкою дванадцятипалої кишки - 14 хворих (39\%).

Вік хворих коливався від 23 до 61 року, середній вік складав $(48 \pm 1,66)$ років.

У І групі хворих із хронічними захворюваннями печінки та поєднаною патологією ШКТ було 14 (64 \%) чоловіків і 8 (36\%) жінок. Серед них було 7 (32\%) хворих із цирозом печінки і 15 (68 \%) хворих із хронічним алкогольним гепатитом. 
Огляди літератури, оригінальні дослідження, погляд на проблему

У II групі всі хворі були з виразковою хворобою дванадцятипалої кишки, серед них було 7 (50\%) чоловіків і 7 (50\%) жінок.

Контрольну групу склали 20 практично здорових осіб без психічної чи соматичної патології віком від 24 до 65 років, в тому числі 11 жінок та 9 чоловіків. Середній вік пацієнтів контрольної групи склав $(41 \pm 2,91)$ років.

Усім хворим II групи проводили фіброезофагогастродуоденоскопію. У 15 (68 \%) хворих було виявлено ерозивне ураження шлунка і ДПК (у 12 хворих - ерозії з локалізацією у воротарній частині шлунка, у 3 - в цибулині ДПК), у 7 (32\%) хворих - гепатогенна виразка з локалізацією у воротарній частині шлунка.

Для виявлення психоемоційних змін та прихованих психологічних розладів ми використовували набір анкетних тестів: тест Люшера (тест вибору кольору), тест САН (тест диференційної самооцінки функціонального стану), опитувальник Спілбергера (шкала реактивної та особистісної тривожності) та опитувальник Айзенка (для визначення рівня нейротизму і показників екстрата інтроверсії). Результати тестування оцінювали в балах.

Результати й обговорення. При обстеженні за методикою Люшера хворих на гепатогенну виразку (ГВ) та хворих на виразкову хворобу дванадцятипалої кишки (ВХ ДПК) результати обох груп хворих ми порівнювали із результатами контрольної групи практично здорових людей. У хворих на гепатогенну виразку, порівняно із особами контрольної групи, виявлено вірогідне підвищення значень тривоги та нестійкості емоційної сфери. Отже, у хворих на ГВ наявний середній рівень тривоги, порівняно із контрольною групою, у якій виявлена незначна ситуаційна тривога; також нестійкою при ГВ $\epsilon$ емоційна сфера, тоді як у осіб контрольної групи вона $\epsilon$ стійкою.

При порівнянні психологічного статусу хворих на виразкову хворобу ДПК (II група хворих) з даними контрольної групи ми виявили зміни, аналогічні змінам при ГВ.

При порівнянні психологічного профілю чоловіків і жінок, хворих на гепатогенну виразку та виразкову хворобу ДПК, ми виявили тенденцію до підвищення рівня тривоги у жінок обох груп та рівня нестабільності емоційної сфери у чоловіків з ГВ, а в ІІ групі - у жінок.

Визначення психологічного статусу проводили при поступленні в стаціонар та перед випискою, тобто після отримання курсу лікування.

Статистично достовірне зниження рівня тривоги (із середньої до деякої ситуаційної) отримано тільки у групі хворих з гепатогенною виразкою.
Аналізуючи психологічний статус хворих на ГВ та ВХ ДПК за методикою Люшера ми виявили, що в обох групах хворих рівень тривоги був середнім і не мав достовірної різниці, а саме: в першій групі становив $(4,82 \pm 0,36)$, у другій групі $(4,64 \pm 0,82)$, що свідчить про достовірну вищу тривогу, порівняно з пацієнтами контрольної групи, які мали показник $(2,40 \pm 0,39)$, що вказує на можливу в нормі деяку ситуаційну тривогу. Рівень тривоги був дещо вищим у жінок, ніж у чоловіків, особливо при ВХ ДПК, але ці показники $\epsilon$ недостовірними.

Показник стану емоційної сфери у обох групах був також близьким: $(5,05 \pm 0,37)$ при ГВ та $(5,36 \pm 0,40)$ при ВX ДПК, що свідчить про достовірну нестійкість емоційної сфери, порівняно 3 контрольною групою практично здорових осіб, у яких показник емоційної сфери вказує на її стійкість $(3,15 \pm 0,51)$.

Отже, за методикою Люшера, як при симптоматичній ГВ, так і при ВХ ДПК значно підвищена тривога супроводжується нестійкістю емоційної сфери. Під впливом лікування у обох групах хворих спостерігалася тенденція до покращення психологічного профілю, але достовірно змінився лише показник тривоги у хворих з симптоматичною ГВ, у яких він від середнього рівня тривоги зменшився до ситуаційної тривожності, тобто до норми.

Вивчаючи загальний стан хворих на ГВ та ВХ ДПК за методикою САН ми порівнювали показники обох груп пацієнтів із показниками контрольної групи; виявили статистично достовірне зниження показників самопочуття, активності та настрою.

Також ми порівнювали обидві групи хворих між собою. Зниження показників самопочуття, активності і настрою у хворих на ВХ ДПК, порівняно із хворими на ГВ, виявилося статистично недостовірним.

При порівнянні показників у обох групах хворих залежно від статі, ми виявили, що нижчі рівні активності, самопочуття та настрою у жінок були статистично недостовірними.

Показники самопочуття, активності та настрою ми порівнювали у динаміці. Ми отримали статистично достовірне підвищення всіх показників після курсу лікування у обох групах хворих.

Самопочуття із поганого стало середнім у обох групах, активність залишилася на середньому рівні, але стала вищою, ніж до лікування, настрій також достовірно підвищився, але залишався в межах середнього показника.

Аналізуючи отримані показники у хворих з симптоматичною гепатогенною виразкою та виразковою хворобою ДПК за методикою САН, ми 
Огляди літератури, оригінальні дослідження, погляд на проблему

виявили достовірне погіршення самопочуття, зокрема $(29,36 \pm 2,29)$ при ГВ та $(28,14 \pm 2,66)$ при ВX ДПК, проти $(46,20 \pm 2,17)$ у практично здорових контрольної групи; зниження активності, а саме $(33,41 \pm 2,78)$ при ГВ та $(33,14 \pm 3,41)$ при ВХ ДПК проти $(49,15 \pm 2,52)$ та погіршення настрою, при ГВ - до показника $(35,36 \pm 2,89)$, а при ВХ ДПК - до $(34,14 \pm 3,45)$ при нормі $(51,75 \pm 2,36)$. Тенденція до нижчих показників спостерігалася у жінок, але вона виявилася недостовірною, як і відносно показників тесту Люшера. Спостерігаючи за динамікою показників САН при закінченні курсу стаціонарного лікування у хворих як з симптоматичною ГВ, так і з ВХ ДПК виявлено достовірне покращення самопочуття (при ГВ - $(35,77 \pm 2,29)$, при ВХ ДПК $(39,43 \pm 2,18))$, активності (при ГВ - $(40,95 \pm 2,73)$, при ВХ ДПК - $(47,21 \pm 2,95))$ та настрою (при ГВ $(44,00 \pm 2,44)$, при ВХ ДПК - $(48,00 \pm 2,45))$. Активність Хворих на ВХ ДПК після лікування навіть досягає рівня практично здорових осіб.

Отже, загальний стан хворих, за даними САН, погіршується в обох групах пацієнтів і значно по- кращується під впливом лікування, хоч далеко не всі показники повністю нормалізуються.

Тестування за методикою Спілбергера у хворих на гепатогенну виразку та виразкову хворобу ДПК виявило, що значення реактивної та особистісної тривожності у них були достовірно вищими, ніж у практично здорових осіб.

Рівні особистісної та реактивної тривожності в обох групах змінювалися односпрямовано і не мали достовірних відмінностей.

Порівнюючи показники за статтю у обох групах хворих ми отримали статистично достовірне підвищення реактивної тривожності (РТ) та особистісної тривожності (ОТ) у жінок, які хворіють на гепатогенну виразку, тоді як у жінок, хворих на виразкову хворобу дванадцятипалої кишки, таке підвищення показників було недостовірним.

Після проведеного лікування відмічено статистично достовірне зниження показників реактивної та особистісної тривожності в обох групах хворих (табл. 1).

Таблиця 1. Динаміка показників реактивної та особистісної тривожності у хворих на гепатогенну виразку та виразкову хворобу до і після курсу лікування

\begin{tabular}{|l|c|c|c|c|}
\hline \multirow{3}{*}{ Тривожність } & \multicolumn{4}{|c|}{ Групи хворих } \\
\cline { 2 - 5 } & \multicolumn{2}{|c|}{ хворі з гепатогенною виразкою } & \multicolumn{2}{|c|}{$\begin{array}{c}\text { хворі з виразковою хворобою } \\
\text { дванадцятипалої кишки }\end{array}$} \\
\cline { 2 - 5 } & до лікування & після лікування & до лікування & після лікування \\
\hline РТ, бали & $36,64 \pm 2,04$ & $29,23 \pm 1,42 \#$ & $32,79 \pm 2,40$ & $23,64 \pm 0,96^{*}$ \\
\hline ОТ, бали & $51,23 \pm 2,05$ & $42,55 \pm 1,68 \#$ & $53,00 \pm 1,92$ & $43,79 \pm 2,34^{*}$ \\
\hline
\end{tabular}

Примітка. \#р<0,05; * $<<0,01$ після лікування.

Аналізуючи дані, отримані за методикою Спілбергера, ми спостерігали підвищені рівні РТ та ОТ в обох групах хворих та достовірне їх зниження після проведеного лікування.

Порівнюючи результати, отримані в обох групах хворих за методикою Айзенка, із даними контрольнї групи, ми виявили достовірне підвищення рівня нейротизму у обох групах, причому у групі хворих з гепатогенною виразкою він був помірно виражений $(15,36 \pm 0,62)$, а в групі хворих 3 виразковою хворобою ДПК - виражений $(16,92 \pm 1,16)$. Показник екстра-інтравертованості у обох групах хворих та контрольній групі свідчить про помірно виражену інтравертованість.
При порівнянні даних показників у чоловіків і жінок в обох групах значні відмінності виявлено тільки за рівнем нейротизму у жінок з ВХ ДПК. Він становить $(19,57 \pm 1,09)$ балів і $\epsilon$ значно вираженим, що свідчить про виражену психоемоційну напруженість. У групі хворих на ГВ рівень нейротизму у жінок теж був підвищений, порівняно із чоловіками, але це підвищення не $\epsilon$ статистично достовірним. У жінок, хворих на виразкову хворобу, також виявлено статистично достовірне підвищення рівня інтравертованості (виражена інтравертованість). У групі хворих ГВ інтравертованість як у чоловіків, так і у жінок, була помірно виражена. Статистично достовірної різниці між ними не було (табл. 2).

Таблиця 2. Середні значення показників психологічного статусу хворих на гепатогенну виразку та виразкову хворобу дванадцятипалої кишки залежно від статі

\begin{tabular}{|l|c|c|c|c|}
\hline \multirow{2}{*}{\multicolumn{1}{c|}{ Показник }} & \multicolumn{4}{|c|}{ Стать } \\
\cline { 2 - 5 } & $\begin{array}{c}\text { чоловіки 3 } \\
\text { гепатогенною виразкою }\end{array}$ & $\begin{array}{c}\text { жінки з гепатогенною } \\
\text { виразкою }\end{array}$ & $\begin{array}{c}\text { чоловіки з виразковою } \\
\text { хворо6ою ДПК }\end{array}$ & $\begin{array}{c}\text { жінки з виразковою } \\
\text { хворобою ДПК }\end{array}$ \\
\hline Екстра-інтраверсія & $12,69 \pm 0,94$ & $10,88 \pm 1,14 \#$ & $13,29 \pm 1,36$ & $9,57 \pm 0,90 *$ \\
\hline Нейротизм & $14,79 \pm 0,72$ & $16,38 \pm 1,10 \#$ & $13,86 \pm 1,14$ & $19,57 \pm 1,09 * *$ \\
\hline
\end{tabular}

Примітка. ** $\mathrm{p}<0,01$; * $\mathrm{p}<0,05 ; \#$ p $>0,05$ порівняно з чоловіками. 
Огляди літератури, оригінальні дослідження, погляд на проблему

Тест Айзенка в обох групах досліджуваних нами хворих на ГВ та ВХ ДПК свідчить про односпрямованість психоемоційних порушень у хворих та їх покращення під впливом лікування. Однак, за тестом Айзенка психоемоційний профіль жінок, хворих ВХ ДПК, погіршується значніше, ніж у чоловіків, на відміну від хворих на ГВ жінок і чоловіків.

Усі тести для дослідження психологічних характеристик хворих на ГВ і ВХ ДПК $\epsilon$ досить інформативними і свідчать про значні порушення психоемоційного статусу в цього контингенту хворих, що слід враховувати при їх лікуванні.

Висновки. У хворих на гепатогенну виразку та виразкову хворобу ДПК $\epsilon$ виражені розлади психоемоційної сфери у вигляді тривожних та депресивних тенденцій, нестійкості емоційної сфери та невротизації особистості:

1. За методикою Люшера в обох групах хворих рівень тривоги виявився середнім і був достовірно вищим, ніж у пацієнтів контрольної групи. Спостерігалася тенденція до дещо вищого рівня тривоги у жінок, ніж у чоловіків, особливо при ВX ДПК. Показник стану емоційної сфери у обох групах свідчить про достовірну нестійкість емоційної сфери, порівняно з контрольною групою практично здорових осіб.

\section{ЛІТЕРАТУРА}

1. Волков В. С. Влияние психических нарушений на течение язвенной болезни / В. С. Волков, Л. Е. Смирнова // Клиническая медицина. - 1996. - № 6. - С. 81-82.

2. Бабак О. Я. Фармакотерапия пептических язв желудка и двенадцатиперстной кишки / О. Я. Бабак, Г. Д. Фадеенко. - Харьков : Основа, 1997. - 150 с.

3. Ивашкин В. T. Helicobacter pylori - революция в гастроэнтерологии / В. Т. Ивашкин, Т. Л. Лапина, Ф. Мегро. - М. : Триада. - Харьков, 1999. - 258 с.

\section{REFERENCES}

1. Volkov, V.S., Smirnova, L.E. (1996). Vliyaniye psikhicheskikh narusheniy na techeniye yazvennoy bolezni [Influence of mental disorders on peptic ulcer disease]. Klinicheskaya meditsina - Clinical Medicine, 6, 81-82 [in Russian].

2. Babak, O.Ya., Fadeenko, G.D. (1997). Farmakoterapiya pepticheskikh yazv zheludka i dvenadtsatiperstnoy kishki [Pharmacotherapy of peptic ulcers of the stomach and duodenum]. Kharkov: Osnova, 150 [in Russian].

3. Ivashkin, V.T., Lapina, T.L., Megro, F. (1999). Helicobacter pylori - revolyutsiya v gastroenterologii [Helicobacter pylori - revolution in gastroenterology]. Moskow: Triada [in Russian].

4. Grinevich, V.B. (2002). Osobennosti yazvennoy bolezni, ne svyazannoy s Helicobacter pylori [Features of
2. За методикою САН ми виявили достовірне погіршення самопочуття, зниження активності та погіршення настрою у обох групах хворих.

3. Тестування за методикою Спілбергера дало можливість виявити, що значення реактивної та особистісної тривожності були достовірно вищими, у порівнянні із практично здоровими особами. Порівнюючи показники за статтю у обох групах хворих ми отримали статистично достовірне підвищення РТ та ОТ у жінок, які хворіють на гепатогенну виразку.

4. Порівнюючи обидві групи хворих за методикою Айзенка із контрольною групою у обох групах ми виявили достовірне підвищення рівня нейротизму. При порівнянні показників чоловіків і жінок у обох групах значні відмінності виявлено тільки за рівнем нейротизму у жінок з виразковою хворобою ДПК, у яких він $є$ значно вираженим.

5. При проведенні дослідження психоемоційного статусу хворих у динаміці відмічено статистично достовірне зниження показників реактивної та особистісної тривожності, покращення самопочуття, активності та настрою після проведення курсу лікування.

4. Гриневич В. Б. Особенности язвенной болезни, не связанной с Helicobacter pylori / В. Б. Гриневич // Терапевтический архив. - 2002. - №2. - С. 24-27.

5. Циммерман Я. С. Психосоматическая медицина и проблема язвенной болезни / Я. С. Циммерман, Ф.В.Белоусов // Клиническая медицина. - 1999. - № 8. - С. 9-16.

6. Ващенко М. А. О6 изменениях нервной системы у больных вирусным гепатитом и циррозом печени / М. А. Ващенко, О. В. Новикова // Вирусы и вирусные заболевания. - 1982. - Вып. 10. - С. 10-15.

peptic ulcer, not associated with Helicobacter pylori]. Terapevticheskiy arkhiv - Therapeutic archive, 2, 24-27 [in Russian].

5. Zimmerman, Ya.S., Belousov, F.V. (1999). Psikhosomaticheskaya meditsina i problema yazvennoy bolezni [Psychosomatic medicine and the problem of peptic ulcer]. Klinicheskaya meditsina - Clinical medicine, 8, 9-16 [in Russian].

6. Vashchenko, M.A., Novikova, O.V. (1982). Ob izmeneniyakh nervnoy sistemy u bolnykh virusnym gepatitom tsirrozom pecheni [On the changes in the nervous system in patients with viral hepatitis and cirrhosis]. Virusy $i$ virusnyye zabolevaniya - Viruses and viral diseases, 10, 1015 [in Russian]. 


\title{
Огляди літератури, оригінальні дослідження, погляд на проблему \\ ГЕПАТОГЕННАЯ ЯЗВА И ЯЗВЕННАЯ БОЛЕЗНЬ ДВЕНАДЦАТИПЕРСТНОЙ КИШКИ: ОСОБЕННОСТИ ПСИХОЭМОЦИОНАЛЬНОГО СТАТУСА БОЛЬНЫХ
}

\author{
๑О. Н. Москаль, Э. И. Архий
}

\section{ГВУз «Ужгородский национальный университет»}

РЕЗЮМЕ. Цель - изучение психологического статуса личности больных язвенной болезнью двенадцатиперстной кишки и симптоматической гепатогенной язвой и выявление его различий при данных заболеваниях.

Материал и методы. Обследовано 36 больных, которые были поделены на две группы: 22 больных с хроническими заболеваниями печени и сочетанной патологией желудочно-кишечного тракта и 14 больных язвенной болезнью двенадцатиперстной кишки. Всем больным проводили общеклинические исследования и для оценки психологического статуса были проведены наборы анкетных тестов: тест Люшера (тест выбора цвета), тест САН (тест дифференциальной самооценки функционального состояния), опросник Спилбергера (шкала реактивной и личностной тревожности) и опросник Айзенка (для определения уровня нейротизма и показателей екстра-и интроверсии). Результаты тестирования оценивали в баллах.

Результаты. По методике Люшера, как при симптоматической гепатогенной язве, так и при язвенной болезни двенадцатиперстной кишки, значительно повышенная тревога сопровождается неустойчивостью эмоциональной сферы. Общее состояние больных, по данным САН, ухудшается в обеих группах пациентов и значительно улучшается под влиянием лечения, хотя далеко не все показатели полностью нормализуются. Анализируя полученные нами данные по методике Спилбергера мы наблюдали повышенные уровни реактивной и личностной тревожности в обеих группах больных и достоверное их снижение после проведенного лечения. Тест Айзенка в обеих группах исследуемых нами больных свидетельствует о однонаправленности психоэмоциональных нарушений у больных и их улучшение под влиянием лечения. Однако, по его результатам, психоэмоциональный профиль женщин, больных язвенной болезнью двенадцатиперстной кишки, ухудшается значительнее, чем у мужчин, в отличие от больных гепатогенной язвой женщин и мужчин.

Выводы.Вобеихгруппахуобследованныхбольныхимеютсявыраженные расстройствапсихоэмоциональной сферы в виде тревожных и депрессивных тенденций, неустойчивости эмоциональной сферы и невротизации личности, что следует учитывать при проведении терапии.

КЛЮЧЕВЫЕ СЛОВА: гепатогенная язва; язвенная болезнь двенадцатиперстной кишки; психологический статус.

\section{HEPATOGENOUS ULCER AND DUODENAL ULCER: FEATURES OF PSYCHOEMOTIONAL STATUS OF PATIENTS}

\section{Uzhhorod National University}

๑O. M. Moskal, E. J. Arhij

SUMMARY. The purpose of this work was to study the psychological status of the personality of patients with duodenal ulcer and symptomatic hepatogenous ulcer and to identify its differences in these diseases.

Material and Methods. 36 patients were examined, which were divided into two groups: 22 patients with chronic liver diseases and combined pathology of the gastrointestinal tract and 14 patients with peptic ulcer of the duodenum. All patients were given general-clinical examinations, and for assessing the psychological status, a set of questionnaire tests were performed: Luscher test (color choice test), SAN test (differential functional self-assessment), Spielberger's questionnaire (reactive and personal anxiety scale), and Eysenck questionnaire (to determine the level of neuroticism and indicators of extraversion and introversion). Test results were evaluated in points.

Results. By the method of Luscher, both in patients with symptomatic hepatogenous ulcers and duodenal ulcer, a significantly increased anxiety is accompanied by instability of the emotional sphere. The general condition of the patients according to the SAN deteriorates in both groups of patients and is significantly improved under the influence of treatment, although not all indicators are fully normalized. Analyzing the data of Spielberger's technique, we observed increased levels of reactive and personality anxiety in both groups of patients and a significant decrease in them after the treatment. The Eysenck test in both groups of investigated patients shows the unidirectionality of psycho-emotional disorders in patients and their improvement under the influence of treatment. However, according to its results, the psycho-emotional profile of women with duodenal ulcer is affected more significantly than in men, in contrast to patients with hepatogenous ulcers in women and men.

Conclusions. In both groups of examined patients there are marked disorders of the psychoemotional sphere in the form of disturbing and depressive tendencies, instability of the emotional sphere and neuroticism of the person, which should be taken into account during therapy.

KEY WORDS: hepatogenous ulcer; duodenal ulcer; psychological status. 